Pesq. Vet. Bras. 29(7):533-544, julho 2009

\title{
Patogênese das lesões associadas à intoxicação por Ramaria flavo-brunnescens em bovinos ${ }^{1}$
}

\begin{abstract}
Maria E. Trost ${ }^{2}$, Glaucia D. Kommers ${ }^{3}$, Claudio S.L. Barros ${ }^{3}$ e Ana L. Schild ${ }^{4}$
ABSTRACT.- Trost M.E., Kommers G.D., Barros C.S.L. \& Schild A.L. 2009. [Pathogenesis of lesions associated with poisoning by Ramaria flavo-brunnescens in cattle.] Patogênese das lesões associadas à intoxicação por Ramaria flavo-brunnescens em bovinos. Pesquisa Veterinária Brasileira 29(7):533-544. Departamento de Patologia, Universidade Federal de Santa Maria, Avenida Roraima 1000, Camobi, 97105-900 Santa Maria, RS, Brazil. E-mail: glaukommers@yahoo.com

The pathogenesis of the lesions of Ramaria flavo-brunnescens poisoning in cattle was studied throughout the retrospective evaluation of selected tissues from nine spontaneous and four experimental cases of the disease. The pathogenesis of lesions observed in the tongue, esophagus, hoof, and tail was investigated analyzing microscopic lesions, histochemical and histochemical-ultrastructural changes. Histochemical techniques utilized were Masson's Trichrome and Selective Oxidation of Keratin (SOK). The histochemicalultrastructural study was acomplished throughout the Swift method under transmission electron microscopy. Hair shafts of the tip of the tail were analyzed under polarized light. Lesions of varying degrees of severity were observed. All changes observed in the keratinized structures studied, mostly in the hard keratin, showed defective keratinization. The morphologic study and the results obtained with SOK and Swift techniques showed that the defective keratinization results of low amounts of sulphur containing amino acids (cystine) in hard keratin structures. This is probably the main pathogenetic mechanism of the lesions observed in $R$. flavo brunnescens poisoning in cattle.
\end{abstract}

INDEX TERMS: Poisonous plants, mushroom poisoning, Ramaria flavo-brunnescens, cattle, keratinization, veterinary pathology.

RESUMO.- O estudo da patogênese da intoxicação pelo cogumelo Ramaria flavo-brunnescens em bovinos foi realizado através da avaliação retrospectiva de tecidos selecionados de nove casos espontâneos e quatro casos experimentais. Para a investigação da patogênese das lesões observadas na língua, esôfago, casco e cauda, foram avaliadas as alterações histopatológicas e aspectos histoquímicos e histoquímico-ultra-estruturais das lesões.

\footnotetext{
${ }^{1}$ Recebido em 18 de Fevereiro de 2009.

Aceito para a publicação em 10 de março de 2009.

Parte da Dissertação de Mestrado do primeiro autor, bolsista do Conselho Nacional de Desenvolvimento Científico e Tecnológico (CNPq).

2 Programa de Pós-Graduação em Medicina Veterinária, área de concentração em Patologia Veterinária, Centro de Ciências Rurais, Universidade Federal de Santa Maria (UFSM), Santa Maria, RS, Brasil.

${ }^{3}$ Depto Patologia, UFSM, Av. Roraima 1000, Camobi, Santa Maria, RS 97105-900. *Autor para correspondência: glaukommers@yahoo.com

${ }^{4}$ Laboratório Regional de Diagnóstico, Faculdade de Veterinária, Universidade Federal de Pelotas (UFPel), Cx. Postal 354, Pelotas, RS 96010-900, Brasil.
}

As técnicas histoquímicas utilizadas foram o Tricrômico de Masson e a oxidação seletiva da ceratina (OSC). O estudo histoquímico-ultra-estrutural foi realizado através da técnica de Swift sob microscopia eletrônica de transmissão. Os pelos da vassoura da cauda foram examinados sob microscopia de luz polarizada. Todas as alterações observadas nas estruturas ceratinizadas estudadas, mas especialmente nas que sofrem ceratinização dura, revelaram defeitos na ceratinização. Aliando ao estudo morfológico os resultados obtidos através da técnica da OSC e da microscopia eletrônica/técnica de Swift pode-se associar os defeitos na ceratinização a uma redução na quantidade de aminoácidos sulfurados (cistina), principalmente nas estruturas que sofrem ceratinização dura, sendo este provavelmente o principal mecanismo patogenético na intoxicação por $R$. flavo brunnescens em bovinos.

TERMOS DE INDEXAÇÃO: Plantas tóxicas, intoxicação por cogumelo, Ramaria flavo-brunnescens, bovinos, ceratinização, patologia veterinária. 


\section{INTRODUÇÃO}

A intoxicação por Ramaria flavo-brunnescens em bovinos é atribuída ao consumo do cogumelo fresco e altamente palatável encontrado no solo de bosques de eucalipto (Santos et al. 1975). Na forma espontânea da intoxicação, os bovinos apresentam emagrecimento, sialorréia, e alisamento e ulceração da superfície dorsal da língua. Os pelos longos da vassoura da cauda se soltam facilmente quando tracionados (Barros et al. 2006). Pode haver hiperemia do rodete coronário e os animais relutam em se mover, ficando em decúbito. Há hiperemia da conjuntiva ocular, hifema e opacidade da córnea. Alguns animais perdem o revestimento córneo dos cascos, dedos acessórios e chifres (Santos 1993). Lesões semelhantes têm sido descritas nos casos experimentais (Santos et al. 1975, Kommers \& Santos 1995, Schons et al. 2007)

As principais lesões envolvem epitélios e especialmente estruturas que sofrem algum grau de ceratinização dura como papilas filiformes da língua, pelos (principalmente da vassoura da cauda) e o estrato laminar do casco (Kommers \& Santos 1995, Schons et al. 2007).

O princípio tóxico de $R$. flavo-brunnescens, não é totalmente conhecido até o presente momento (Tokarnia et al. 2000). Há duas hipóteses para a patogênese das lesões observadas na intoxicação pelo cogumelo em bovinos (Kommers \& Santos 1995) e em ovinos (Sallis et al. 2000). A hipótese proposta para bovinos é de que o princípio tóxico interfira no metabolismo dos aminoácidos sulfurados nos ceratinócitos, principalmente da cistina, resultando no enfraquecimento da estrutura molecular da ceratina dura (Kommers \& Santos 1995). O mecanismo proposto para os ovinos é de que ocorram lesões vasculares e isquêmicas, semelhantes às do ergotismo (Sallis et al. 2000).

Neste estudo, que avalia simultaneamente casos espontâneos e experimentais da intoxicação pelo cogumelo em bovinos, teve-se o objetivo de analisar detalhadamente as alterações morfológicas observadas na língua, esôfago, casco e cauda, bem como avaliar através de técnicas histoquímicas e histoquímico-ultra-estruturais as alterações nas propriedades estruturais e químicas da ceratina dura nos tecido lesados, a fim confirmar ou não o mecanismo patogenético proposto para a intoxicação de bovinos por $R$. flavo-brunnescens.

\section{MATERIAL E MÉTODOS}

Para o estudo da patogênese da intoxicação por Ramaria flavobrunnescens foram utilizadas amostras provenientes de dois surtos (total de 9 bovinos; surto A com 6 bovinos [Bovinos 1-6] e surto $B$ com 3 bovinos [Bovinos 7-9]) e de dois estudos experimentais (total de 4 bovinos; estudo $A$ com 3 bovinos [Bovinos 13-15] e estudo B com 1 bovino [Bovino 16]). Dados epidemiológicos e clínico-patológicos dos casos espontâneos foram publicados por Barros et al. (2006). Informações semelhantes referentes a três casos experimentais (estudo A) foram publicadas por Schons et al. (2007).

As alterações clínicas e macroscópicas foram brevemente relatadas. Para a investigação da patogênese das lesões ob-
Quadro 1. Dados de resenha dos bovinos e parâmetros avaliados em tecidos selecionados dos casos de intoxicação espontânea por Ramaria flavo-brunnescens

\begin{tabular}{|c|c|c|c|c|c|c|c|}
\hline \multicolumn{4}{|c|}{ Dados do animal } & \multicolumn{4}{|c|}{ Parâmetros avaliados } \\
\hline Número & Raça & Sexo & Idade & $\mathrm{HE}$ & OSC & Masson & Polarização \\
\hline 1 & Mista & Macho & 1 ano & - & - & - & - \\
\hline 2 & Mista & Macho & 18 meses & - & - & - & - \\
\hline 3 & Mista & Macho & 19 meses & - & - & - & - \\
\hline 4 & Mista & Macho & 18 meses & - & - & - & - \\
\hline 5 & Mista & Macho & 18 meses & - & - & - & - \\
\hline 6 & Mista & Macho & 18 meses & - & - & - & - \\
\hline 7 & Mista & Macho & 22 meses & - & - & - & - \\
\hline 8 & Mista & Macho & 22 meses & - & - & - & - \\
\hline 9 & Mista & Macho & 22 meses & - & - & - & - \\
\hline $10^{*}$ & Mista & Fêmea & 4 anos & - & - & - & - \\
\hline $11^{*}$ & Mista & Fêmea & 2 anos & - & - & - & - \\
\hline $12^{*}$ & Mista & Fêmea & 2 anos & - & - & - & - \\
\hline
\end{tabular}

* Bovino controle; $\bullet=$ parâmetro avaliado (em seções selecionadas de língua, esôfago, casco, cauda ou de hastes pilosas da vassoura da cauda); HE = hematoxilina-eosina; OSC = oxidação seletiva da ceratina; Masson $=$ Tricrômico de Masson.

Quadro 2. Dados de resenha dos bovinos e parâmetros avaliados em tecidos selecionados dos casos de intoxicação experimental por Ramaria flavo-brunnescens

\begin{tabular}{|c|c|c|c|c|c|c|c|}
\hline \multicolumn{4}{|c|}{ Dados do animal } & \multicolumn{4}{|c|}{ Parâmetros avaliados } \\
\hline Número & Raça & Sexo & Idade & HE OSC & Masso & & H-ME \\
\hline 13 & Jersey & Macho & 9 meses & - & - & - & - \\
\hline 14 & Jersey & Macho & 9 meses & - & - & - & - \\
\hline 15 & Jersey & Macho & 9 meses & - & - & - & - \\
\hline 16 & Mista & Fêmea & 8 meses & - & - & - & - \\
\hline $17^{\star}$ & Jersey & Macho & 9 meses & - & - & - & - \\
\hline
\end{tabular}

* Bovino controle; $\bullet$ = parâmetro avaliado (em seções selecionadas de língua, esôfago, casco, cauda ou de hastes pilosas da vassoura da cauda); - = parâmetro não avaliado; $\mathrm{HE}$ = hematoxilina-eosina; OSC = oxidação seletiva da ceratina; Masson = Tricrômico de Masson; $\mathrm{H}$ $\mathrm{ME}=$ método histoquímico-ultra-estrutural.

servadas na língua, esôfago, casco e pele da cauda, foram avaliadas as alterações histopatológicas e aspectos histoquímicos e histoquímicos-ultra-estruturais em tecidos selecionados. Dados de resenha dos bovinos e parâmetros avaliados são apresentados no Quadro 1 (casos espontâneos) e Quadro 2 (casos experimentais).

As amostras haviam sido fixadas em formol a $10 \% \mathrm{e}$ processadas rotineiramente para histopatologia. As técnicas histológicas e histoquímicas deste estudo foram realizadas a partir de blocos de parafina já existentes ou de blocos provenientes de novos encaminhamentos.

Foram avaliadas as alterações histopatológicas e aspectos histoquímicos em seções de língua (região cranial), esôfago, casco (estrato laminar) e pele da região da vassoura da cauda. Amostras dos mesmos tecidos estudados foram obtidas de quatro bovinos (Bovinos 10, 11, 12 e 17) sem alterações nos locais avaliados e utilizados como controles. Para o estudo histopatológico, múltiplas seções de língua, esôfago, casco e pele da região da vassoura da cauda foram coradas pela hematoxilina-eosina (HE).

O estudo histoquímico foi realizado em seções da língua, casco e cauda através dos métodos de oxidação seletiva da ceratina (OSC) e do Tricrômico de Masson. A técnica da OSC foi realizada de acordo com Pearse (1951), modificada por Lillie 
\& Bangle (1954). Resumidamente, blocos de parafina contendo seções de língua, casco ou cauda foram cortados em $5 \mu \mathrm{m}$. As lâminas foram desparafinizadas e posteriormente imersas em solução oxidante de ácido peracético. Após, as lâminas foram lavadas por 3 min em água corrente e o reagente de Schiff foi pingado sobre os cortes permanecendo sobre os mesmos por $30 \mathrm{~min}$. As lâminas foram lavadas em água corrente quente por 10 min, desidratadas em alcoóis, clarificadas em xilol e montadas em resina sintética e lamínulas. Para o Tricrômico de Masson utilizou-se o Kit EasyPath Tricrômio de Masson com azul de anilina (Erviegas, cód. EP-142051).

Foram avaliadas ultra-estruturalmente cutículas de pelos da vassoura da cauda de um bovino (Bovino 16), intoxicado experimentalmente conforme metodologia descrita por Kommers \& Santos (1995). Resumidamente, num período de 15 dias, o bovino recebeu oito administrações de $20 \mathrm{~g} / \mathrm{kg}$ de cogumelo fresco. Para a determinação da região dos pelos a ser avaliada pela microscopia eletrônica de transmissão, antes da primeira administração (dia 0) os pelos da vassoura da cauda do Bovino 16 (de pelagem branca) foram pintados com tintura para cabelos da cor castanho-escura, tomando-se o cuidado para que a tintura atingisse a pele subjacente. Após 40 minutos, a tintura foi removida com água e sabão glicerinado. Logo a seguir, foi colhida por tração a primeira amostra de pelos que serviu como controle. Hastes de pelos também foram colhidas no $5^{\circ}, 10^{\circ}$ e $15^{\circ}$ dias subseqüentes. Fragmentos de pelos colhidos nos dias $0,5,10 \mathrm{e}$ 15 (cinco hastes com $2 \mathrm{~mm}$ de comprimento) foram cortados (localização conforme a Fig.1), embebidos em éter etílico por 24 horas (para desengordurar), desidratados em álcool absoluto (2 vezes de 30 minutos) e incluídos em resina epóxi. Cortes semifinos foram corados pelo azul de toluidina para exame em microscopia de luz, visando selecionar os pelos para os cortes ultra-finos. Cortes ultra-finos foram colocados em grades de ouro sobre os quais aplicou-se a técnica de Swift (Swift 1967) para o estudo histoquímico-ultra-estrutural do conteúdo de cistina em fotomicrografias (obtidas em microscópio Zeiss-EM 10) de seções transversais das células cuticulares pilosas.

Para o exame polaroscópico, pelos controle (dia 0) e colhidos nos dias 5, 10 e 15 do bovino 16 foram fixados em lâmina histológica com fita adesiva, deixando livre somente a parte branca (não corada pela tintura) que correspondia, no dia 0 , à porção do pelo que encontrava-se dentro do folículo piloso. No caso dos dias 5, 10 e 15, examinou-se a porção inferior da haste (que cresceu sob influência do princípio tóxico do cogumelo, conforme a Fig.1). Hastes pilosas dos bovinos intoxicados espontaneamente foram também avaliadas sob luz polarizada.

\section{RESULTADOS}

A intoxicação espontânea (surtos A e B) por Ramaria flavobrunnescens em bovinos cursou com alterações clínicopatológicas que incluíram alisamento da superfície dorsal da língua, com perda das papilas filiformes e áreas de ulceração, ulceração esofágica e afrouxamento e queda dos pelos, principalmente da vassoura da cauda. Nos bovinos experimentais (estudos $A$ ), as alterações foram semelhantes, porém mais brandas, não tendo sido observadas alterações esofágicas.

As principais alterações histopatológicas observadas na língua dos bovinos intoxicados, tanto espontaneamente como experimentalmente envolveram a superfície dorsal.

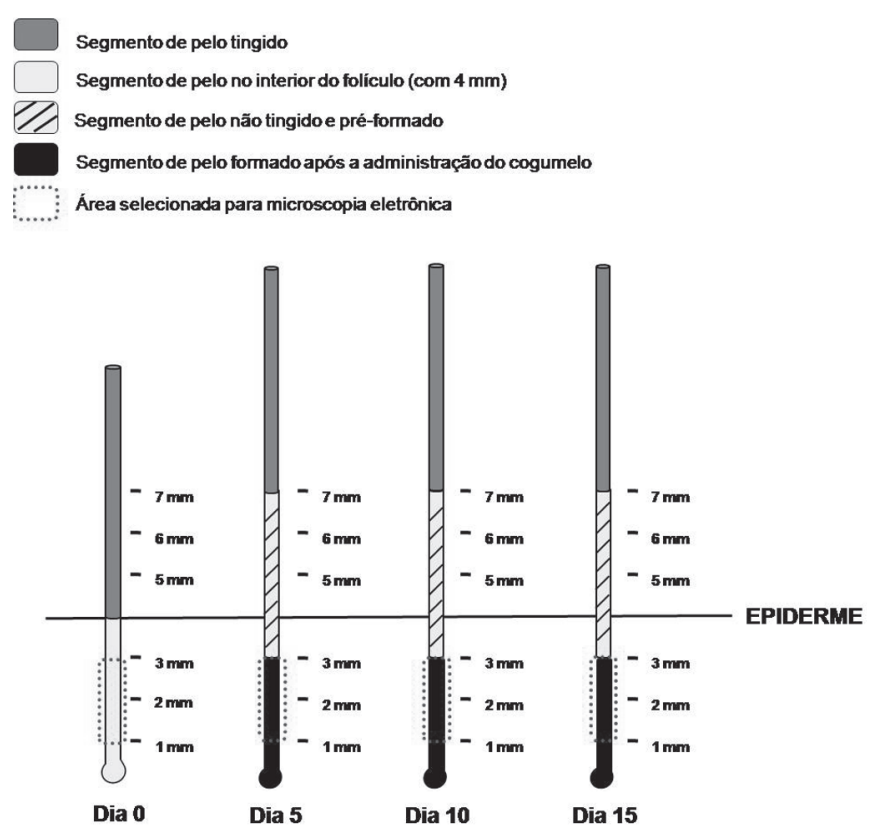

Fig.1. Representação esquemática do crescimento dos pelos do Bovino 16 durante o experimento com demonstração da área de colheita de material para microscopia eletrônica de transmissão (Técnica de Swift).

Mais freqüentemente ocorreram adelgaçamento do epitélio, desaparecimento de papilas filiformes e ulceração multifocal associada a tecido fibrovascular subjacente. Reepitelização, projeções irregulares do epitélio para a lâmina própria, estratificação irregular do epitélio, formação de ceratina lamelar, ceratinização individual e vacuolização citoplasmática de ceratinócitos também foram observadas.

Uma alteração presente em todos os casos foi o adelgaçamento do epitélio da língua, que em casos acentuados tinha cerca de $1 / 3$ da espessura do epitélio de uma língua normal. A diminuição na espessura do epitélio dos casos em que não havia ulceração envolveu a totalidade da superfície dorsal da língua examinada. Porém, nos casos com ulceração, observou-se que o adelgaçamento era ainda mais pronunciado nas áreas adjacentes às úlceras.

Quanto às papilas filiformes, as lesões variaram de leve atenuamento até o desaparecimento total dessas estruturas (Fig.2A,B). Observaram-se alterações morfológicas inicialmente na base das papilas com desorganização dos ceratinócitos, muitos deles com vacúolos e depósitos eosinofílicos densos intracitoplasmáticos.

Pela técnica do Tricrômico de Masson observou-se alteração na coloração das papilas filiformes (mudança da coloração de amarelo para vermelho) quando comparadas às línguas controle (Fig.3A,B). Observou-se marcada redução na intensidade da coloração da ceratina dura do centro das papilas filiformes (mudança de rosaforte para rosa-claro), evidenciada pela técnica de oxidação seletiva da ceratina (Fig.4A,B). 

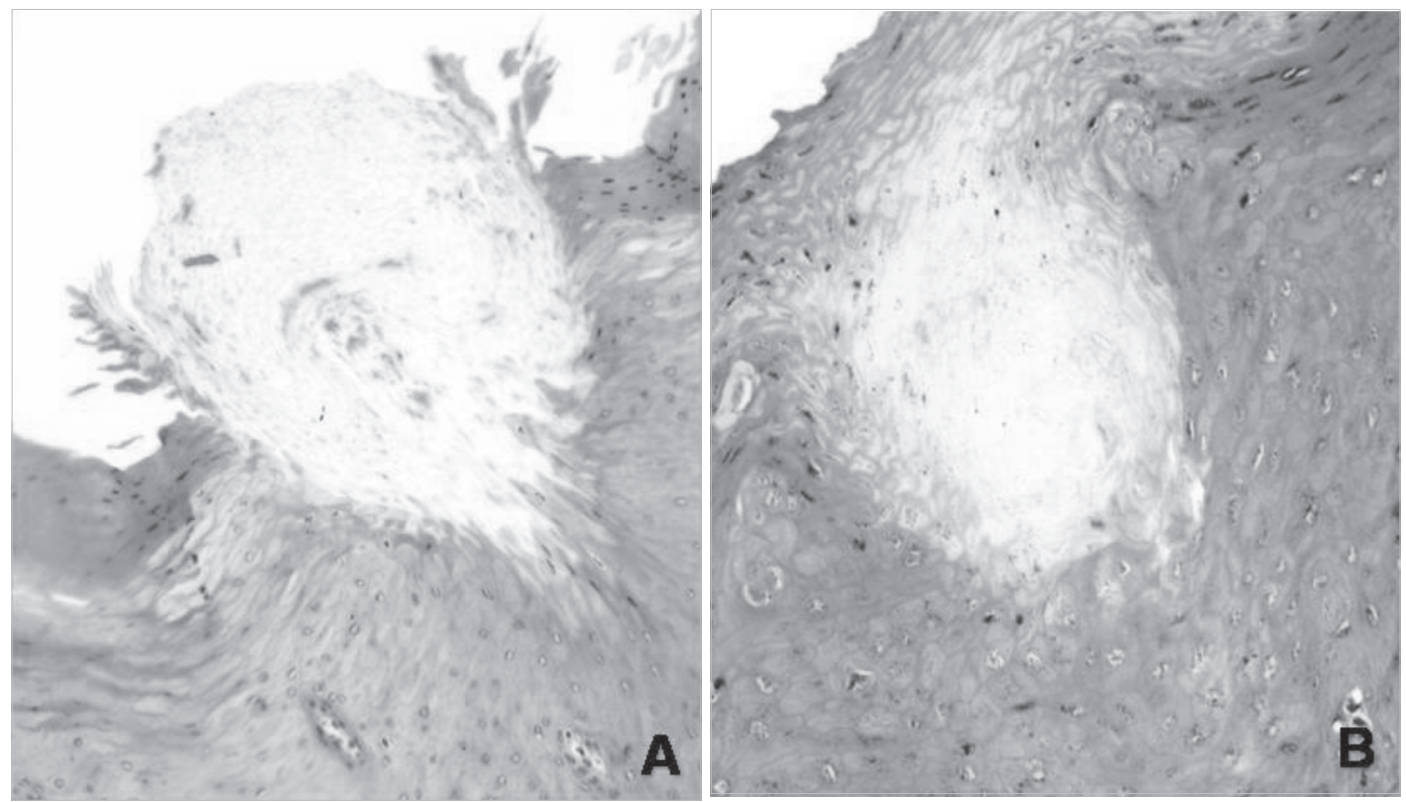

Fig.2. Papila filiforme lingual. (A) Papila normal (Bovino 10, controle). HE, obj.20x. (B) Papila atenuada (Bovino 6). HE, obj.20x.

As úlceras foram freqüentemente observadas (7/12) e eram focais, multifocais ou envolviam todo o epitélio dorsal. Eram recobertas por variável quantidade de fibrina e agregados bacterianos basofílicos intralesionais e associadas a infiltrado inflamatório com predomínio de neutrófilos, macrófagos, linfócitos e tecido fibrovascular. O tecido fibrovascular na lâmina própria subjacente às regiões ulceradas era caracterizado por proliferação de fibroblastos, acúmulo de colágeno e numerosos vasos sanguíneos

neoformados. Em muitas áreas havia um epitélio estreito (re-epitelização) recobrindo área de tecido fibrovascular.

Em muitas línguas (6/12) foram observadas projeções irregulares do epitélio para a lâmina própria. Nas extremidades destas projeções (que às vezes eram visualizadas como ninhos desconectados do epitélio), em muitos casos, havia ceratinização lamelar central. Observou-se, ocasionalmente, estratificação irregular do epitélio lingual (Bovinos 4 e 6). Nessas áreas os ceratinócitos perdiam sua
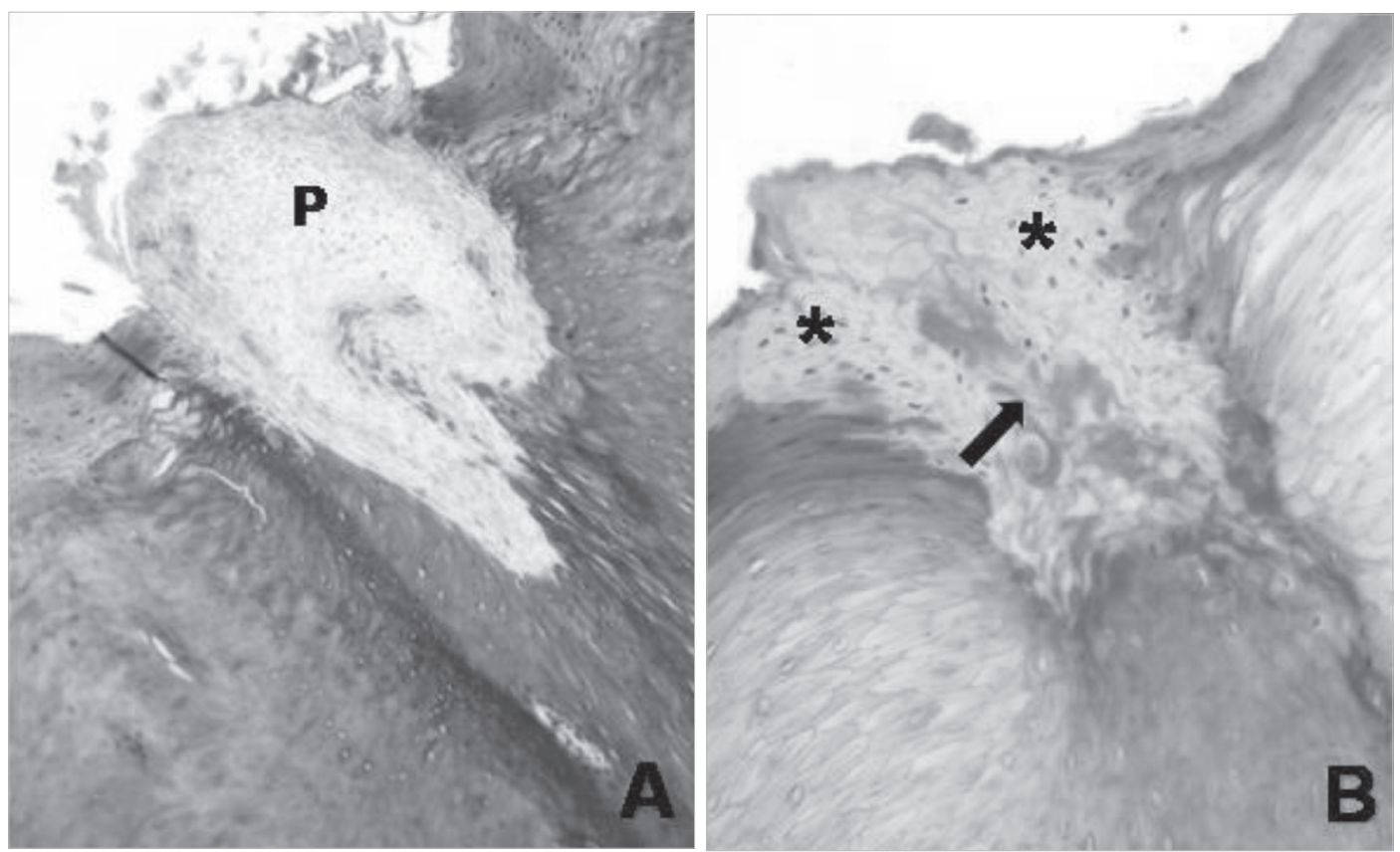

Fig.3. Papila filiforme lingual. Tricrômico de Masson. (A) Papila normal (Bovino 10, controle): a porção central da papila (P) é corada de amarelo-brilhante. Obj.20x. (B) Papila atenuada (Bovino 6): a papila é menor, corada de amarelo menos intenso $\left(^{*}\right)$ e há áreas centrais coradas em vermelho (seta). Obj.20x. 


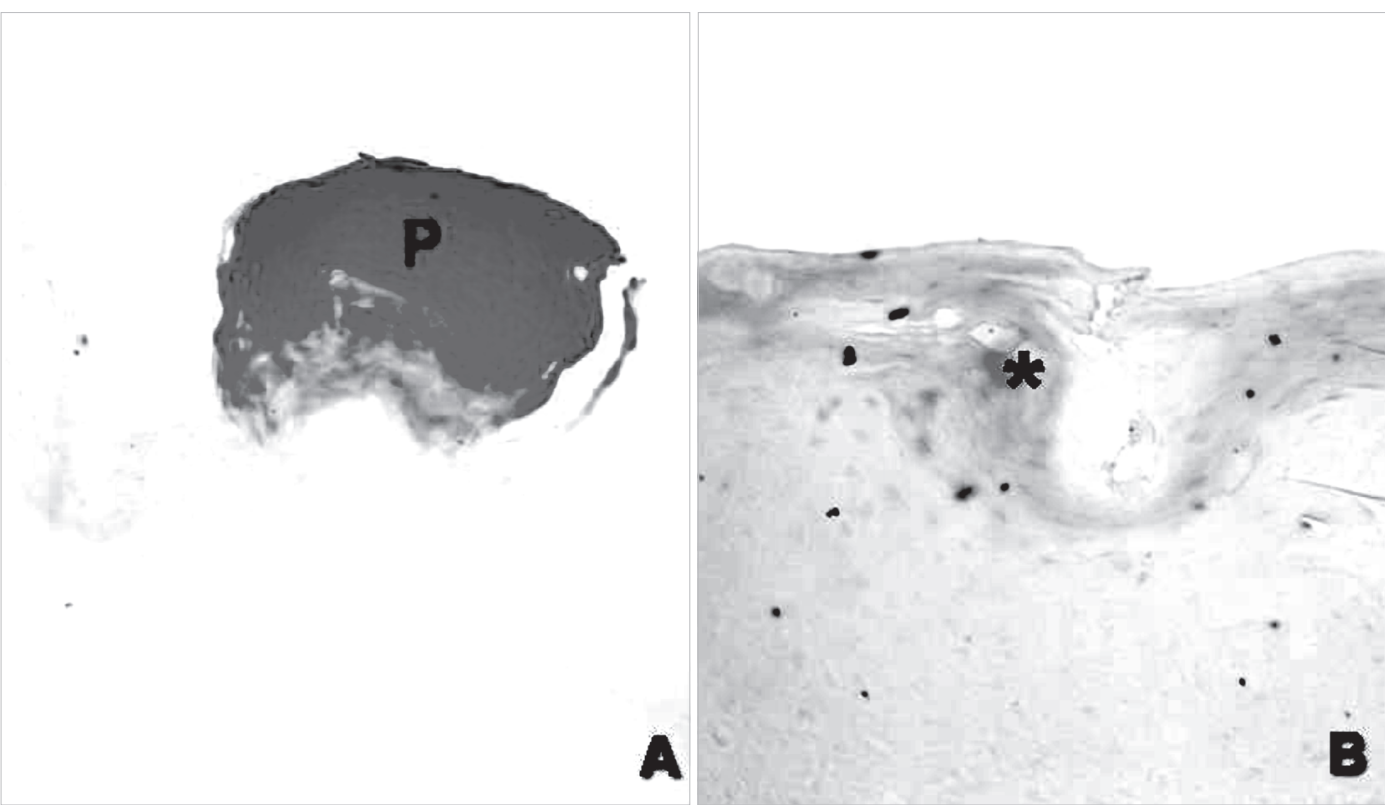

Fig.4. Papila filiforme lingual. Oxidação seletiva da ceratina. (A) Papila normal (Bovino 10, controle): a papila $(P)$ é corada de rosa-forte. Obj.20x. (B) Resquício de papila (Bovino 8): observa-se que permanece apenas o resquício da papila $\left(^{*}\right)$ corada em rosa-claro. Obj.20x.

orientação normal e formavam pequenos grupos em arranjo concêntrico (Fig.5A). Em metade das línguas analisadas havia ceratinização individual de células caracterizada por ceratinócitos arredondados, circundados por um halo claro, com citoplasma fortemente eosinofílico e núcleo pequeno e hipercromático (Fig.5B). Essas células eram distribuídas aleatoriamente pelo epitélio, porém pareciam mais abundantes na região suprabasal. Ocasionalmente havia ceratinócitos com vacúolos citoplasmáticos.

Todos os esôfagos analisados apresentaram algum grau de redução na espessura epitelial, sendo, na maioria dos casos, moderado (Fig.6A,B). Ulceração foi um achado muito freqüente $(6 / 12)$. As úlceras eram recobertas por fibrina, debris celulares e neutrófilos íntegros e degenerados. Em muitos locais foram observados agregados bacterianos basofílicos intralesionais. Em áreas subjacentes às úlceras havia graus variáveis de proliferação de tecido fibrovascular e re-epitelização. Ocasionalmente observou-se epitélio exibindo projeções irregulares para a submucosa e áreas do epitélio com ceratinócitos com morfologia alterada e vacuolização.

Nos cascos em que havia lesões (10/12) essas envolviam as lâminas epidérmicas do estrato laminar que apresentavam graus variáveis de fusão, encurtamento, múlti-
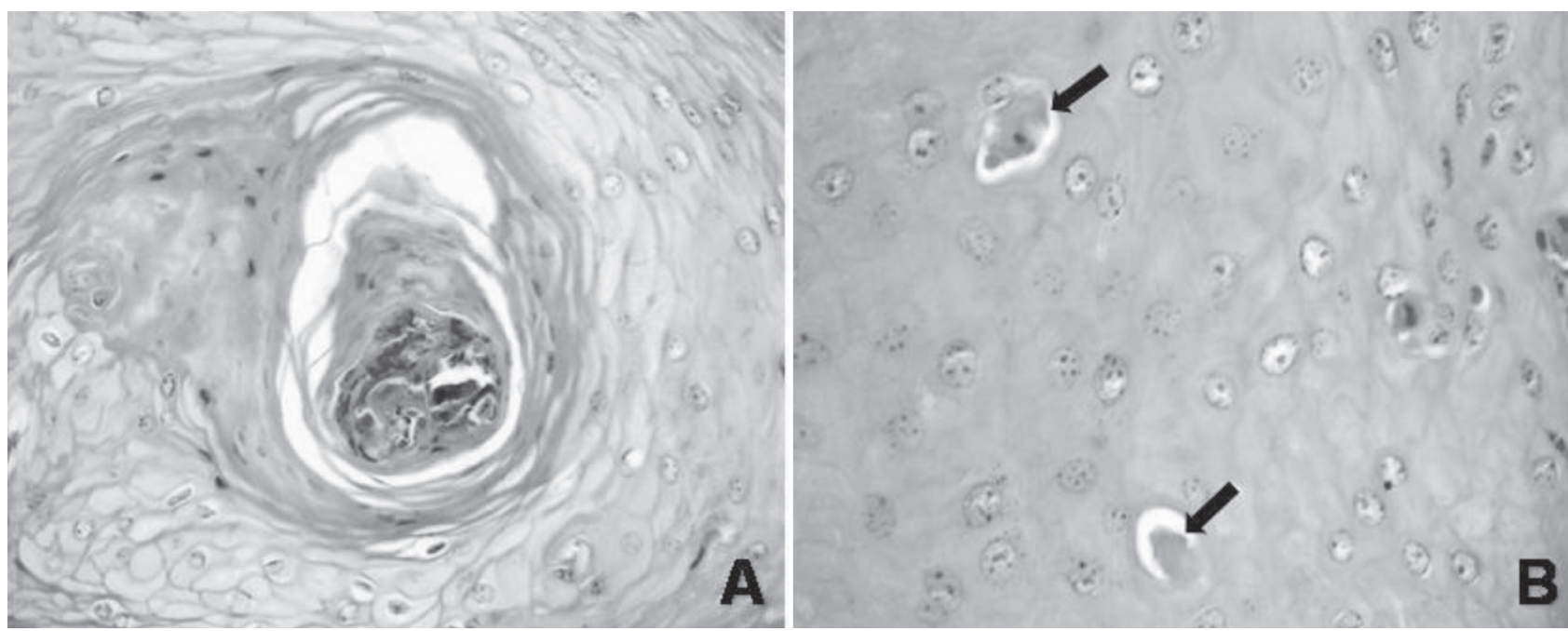

Fig.5. Epitélio dorsal lingual (Bovino 6). Hematoxilina-eosina. (A) Observa-se perda da orientação normal dos ceratinócitos e formações concêntricas Obj.20x. (B) Observam-se ceratinócitos disceratóticos (setas); circundados por halo claro, com citoplasma fortemente eosinofílico e núcleo pequeno e hipercromático (seta). Obj.40x. 


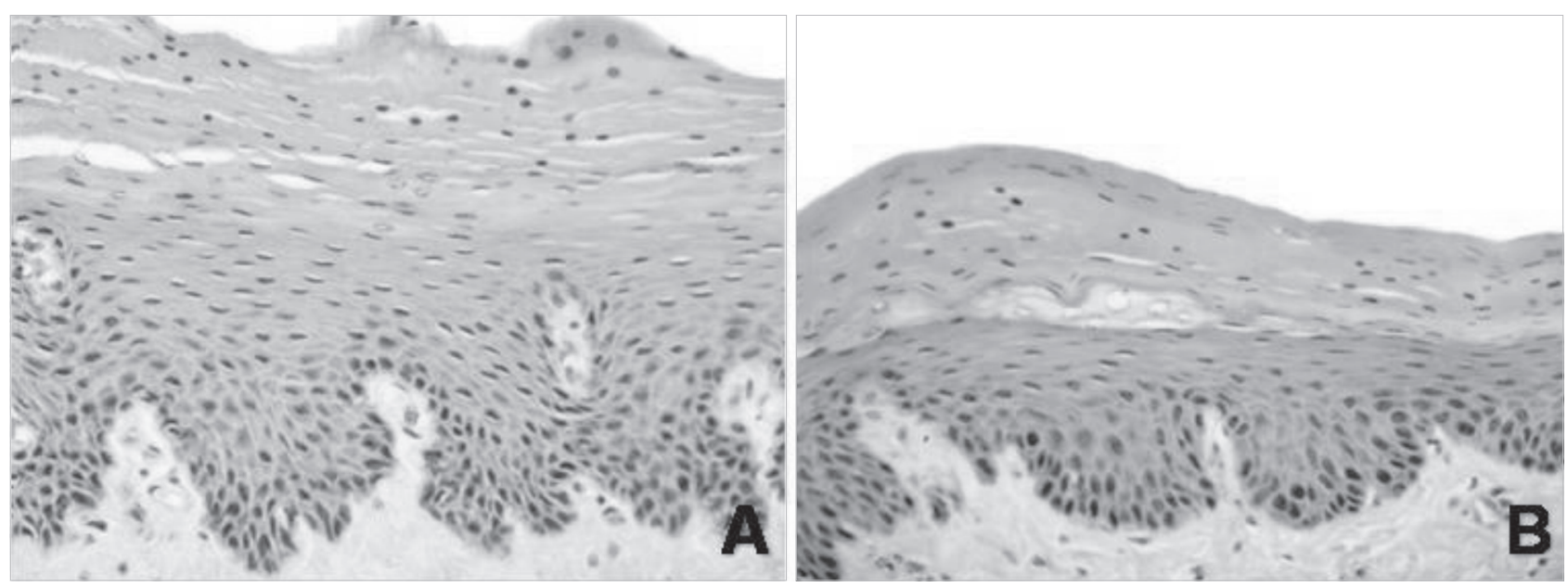

Fig.6. Epitélio esofágico. Hematoxilina-eosina. (A) Epitélio normal (Bovino 10, controle). Obj.20x. (B) Redução expressiva da espessura epitelial (Bovino 6). Obj.20x.

plas camadas de células não-ceratinizadas no topo, ceratinização irregular e descontínua com persistência de núcleos, ceratinização individual e vacuolização de ceratinócitos.

Fusão de lâminas ocorreu em metade dos cascos analisados, em qualquer nível, no entanto foram mais comuns no topo das lâminas (Fig.7A,B). Da mesma forma, em metade dos cascos avaliados observou-se encurtamento de lâminas epidérmicas.

Em muitos cascos havia maior número de camadas de células no topo das lâminas e muitos ceratinócitos apresentavam alterações morfológicas como vacuolização e acúmulos citoplasmáticos eosinofílicos. Alterações na ceratina laminar foram vistas em vários casos (8/12). Estas alterações atingiram grupos de lâminas seqüenciais, aleatórias ou ocorreram em todo o fragmento de casco analisado.

A partir da camada basal nas lâminas epidérmicas, havia uma desorganização na disposição dos ceratinócitos e na sua diferenciação. Observavam-se várias camadas de ceratinócitos, muitos deles vacuolizados, e ausência da ceratinização ab-rupta do centro das lâminas. Persistência de núcleos era observada em meio à ceratina formada defeituosamente. Ceratinização individual de células foi vista em muitos casos (7/12) e ocorreu por todo o epitélio laminar mesmo em regiões em que as alterações descritas anteriormente não foram observadas.

Através do uso do Tricrômico de Masson observou-se que a ceratina laminar defeituosa formada era irregular, fragmentada ou em casos graves, reduzida a pequenos segmentos ceratinizados (Fig.8A,B). A ceratina laminar defeituosa, observada pela coloração de rotina, teve uma reação muito fraca pela técnica da oxidação seletiva da ceratina, quando comparada a cascos normais.

Muitos folículos pilosos da cauda dos bovinos intoxicados por $R$. flavo-brunnescens não tinham haste de pelo em seu interior (as vezes substituída por um plugue de ceratina [ceratose folicular]) ou estavam em fase telógena.
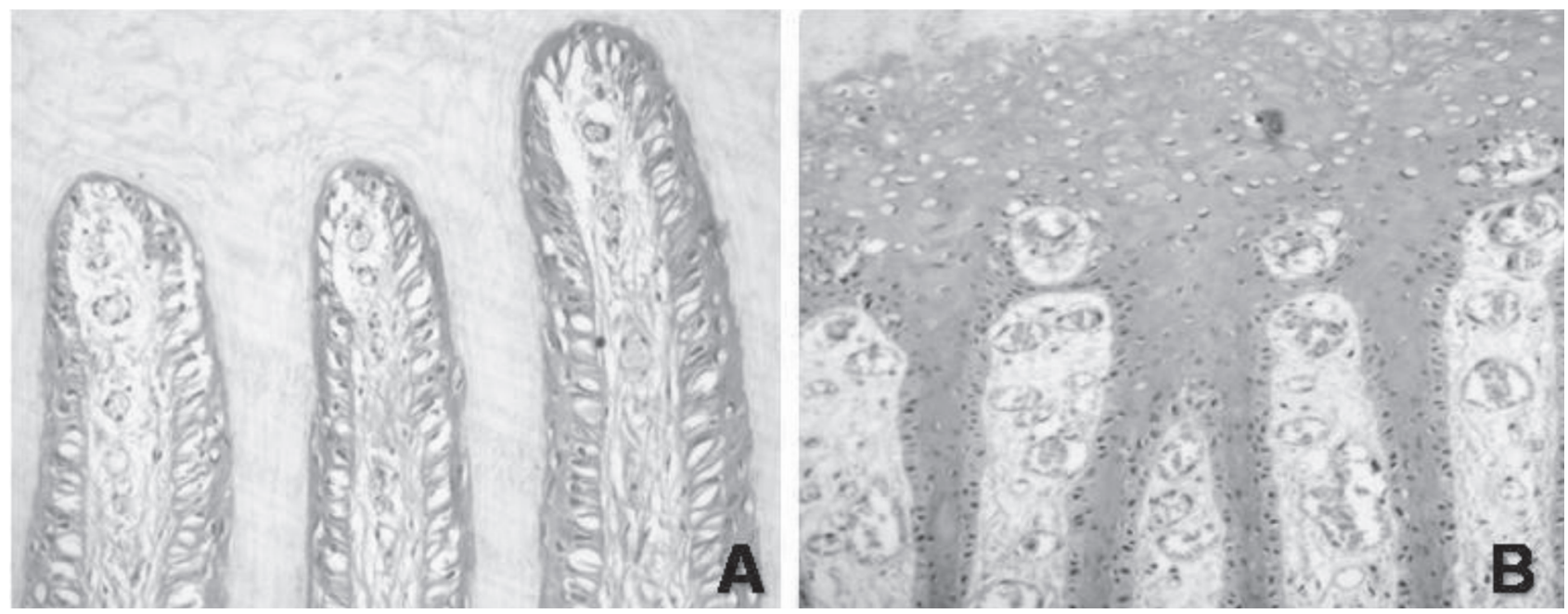

Fig.7. Região laminar do casco. Hematoxilina-eosina. (A) Casco normal (Bovino 11, controle). Obj.20x. (B) Fusão do topo das lâminas epidérmicas (Bovino 6). Obj.10x. 

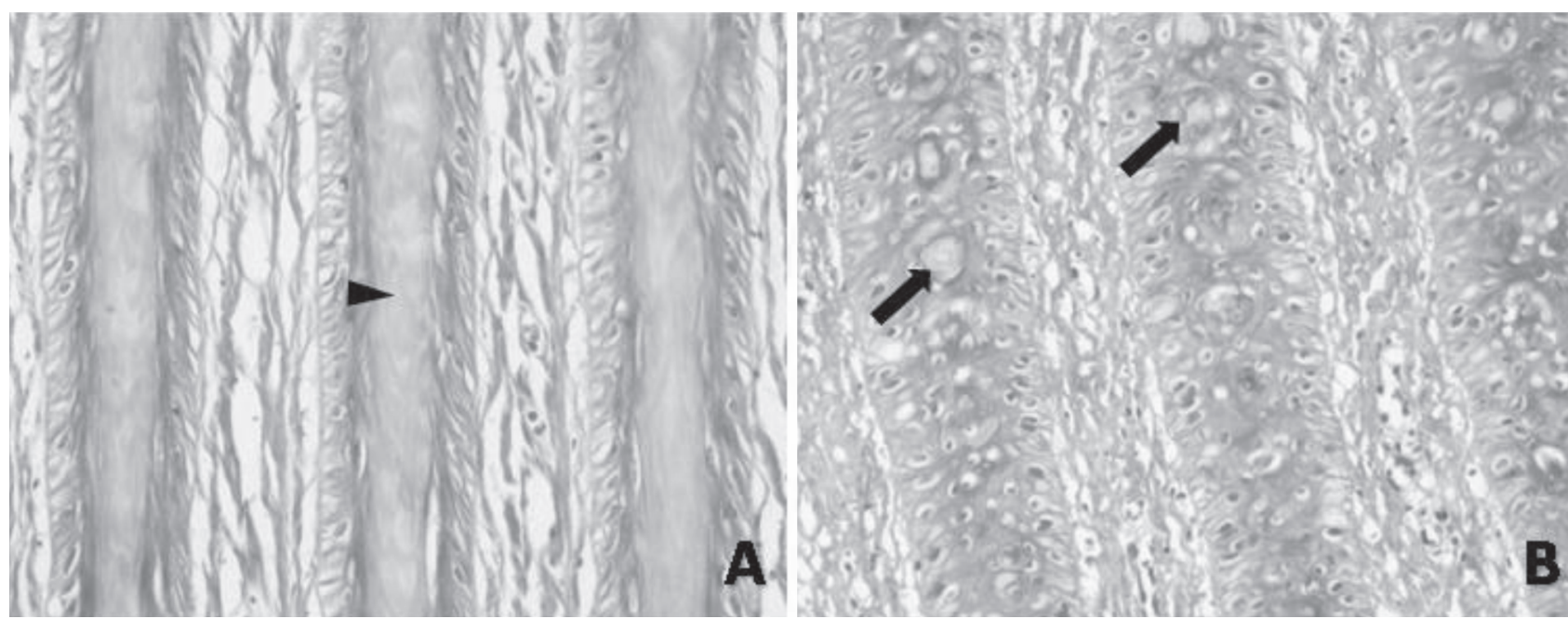

Fig.8. Região laminar do casco. Tricrômico de Masson. (A) Epitélio laminar normal (Bovino 11, controle). Observa-se a ceratina laminar contínua corada em amarelo (cabeças de seta). Obj.20x. (B) Fragmentos de ceratina laminar aparecem em amarelo (setas) (Bovino 1). Obj.20x.

Virtualmente todos os folículos pilosos e pelos apresentaram algum tipo de alteração. Nos casos de intoxicação experimental (Bovinos 13, 14 e 15), as alterações observadas foram mais sutis que na intoxicação espontânea.

As alterações morfológicas nos folículos pilosos, na maioria dos casos, eram moderadas a severas e envolveram tanto a bainha radicular externa (BRE) quanto a bainha radicular interna (BRI). Muitos folículos tinham os contornos internos e externos alterados e ocasionalmente havia espessamento da bainha radicular fibrosa. Em um grande número de folículos observou-se que a BRE estava espessada e as células eram desalinhadas (Fig.9A e B). Nesta estrutura, a ceratinização individual de células e ceratinócitos com vacúolos claros intracitoplasmáticos foi um achado muito constante. Como na BRE, as alterações na BRI foram muito freqüentes. Na maioria dos casos se caracterizaram por arranjo irregular de células, células desintegradas e finalmente, degeneração total da estrutura (Fig.9A,B).

Em relação às alterações nas hastes pilosas, estas variaram de pelos com alterações leves nos casos experimentais a pelos com contornos irregulares, extremamente tortuosos e desintegrados nos casos de intoxicação espontânea. Nos casos de alterações pilosas acentuadas, a identificação da haste muitas vezes se tornou difícil pela coloração de rotina. Nestes casos, a haste pilosa foi melhor visualizada através da técnica do Tricrômico de Masson, na qual hastes e fragmentos de pelo coraram irregularmente de amarelo. Quando aplicada a técnica da OSC, os pelos dos bovinos intoxicados demonstraram

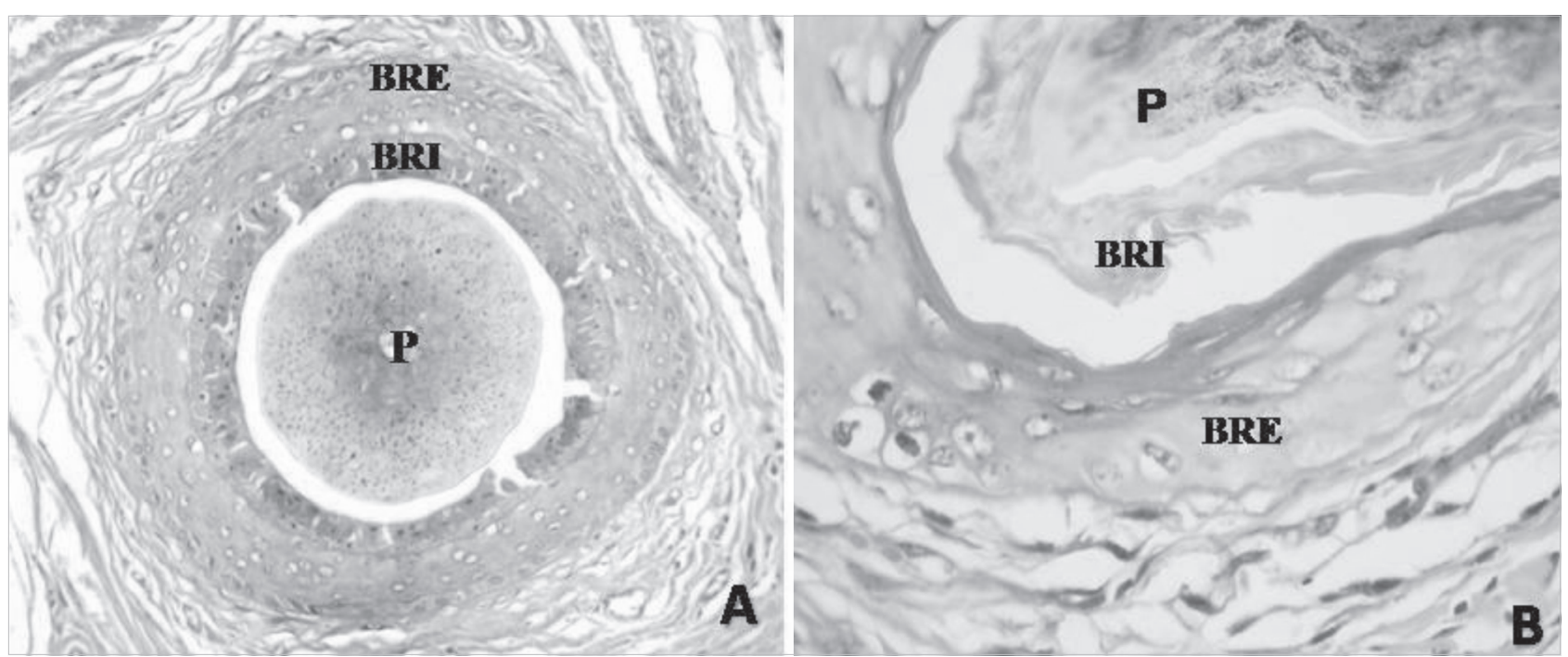

Fig.9. Folículos pilosos da pele da região da vassoura da cauda. Hematoxilina-eosina. (A) Folículo piloso (bainha radicular externa $[B R E]$ e bainha radicular interna $[B R I])$ e pelo $(P)$ normais (Bovino 12, controle). Obj10x. (B) Desorganização das células da BRE, BRI degenerada e pelo (P) desintegrado (Bovino 1). Obj.40x. 

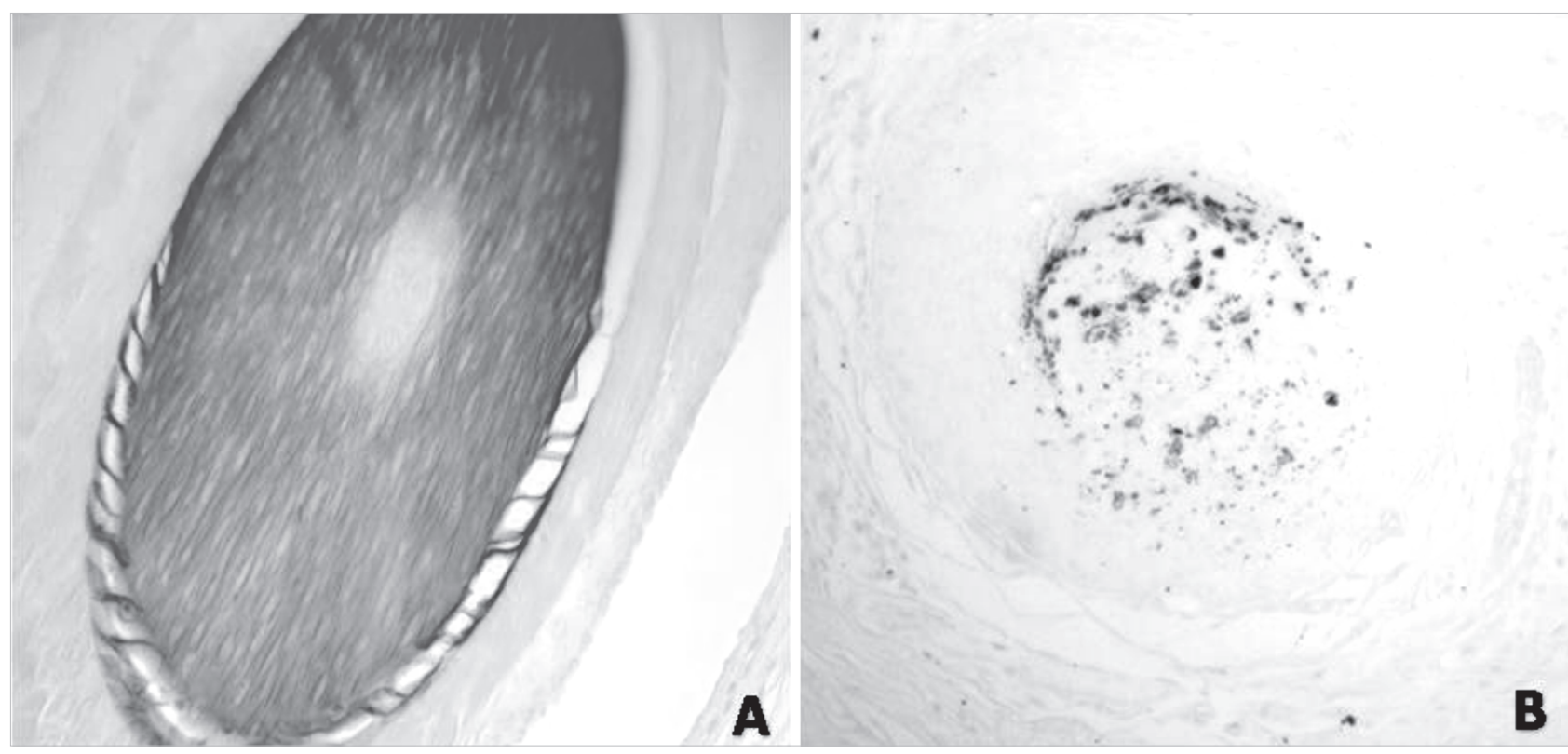

Fig.10. Folículos pilosos e pelos da pele da região da vassoura da cauda. Oxidação seletiva da ceratina. (A) Corte transversal de pelo normal (Bovino 12, controle): o pelo é homogeneamente corado de rosa-forte. Obj.20x. (B) Corte de pelo (Bovino 8): há fragmentos de pelo corados de rosa-claro. Obj.20x.

uma redução expressiva na intensidade da coloração e foram identificados como estruturas coradas de rosa-claro, enquanto os pelos normais de bovinos controle se coraram de rosa-forte (Fig.10A,B).

Nas hastes de pelos coletadas dos bovinos intoxicados espontaneamente e do Bovino 16 (experimental), e observadas em microscopia de luz polarizada, havia alterações tanto morfológicas quanto no padrão de birrefringência. Quanto à morfologia, havia hastes de pelo com contornos irregulares (Fig.11A e B), tortuosas e onduladas. Em alguns casos observou-se torção longitudinal do eixo da haste pilosa (Fig.11C). Em relação à birrefringência, os pelos afetados apresentaram polarização irregular ou ausente em algumas áreas, quando comparados aos pelos controle, nos quais a polarização era uniforme.

No experimento realizado com o Bovino 16 foi demonstrado que nos cinco primeiros dias do experimento a taxa de crescimento dos pelos foi de aproximadamente $0,6 \mathrm{~mm} /$ dia (totalizando $3 \mathrm{~mm}$ de pêlo que cresceu após o início da administração do cogumelo) e que a partir do $5^{\circ}$ dia os pelos eram arrancados facilmente ao ser efetuada uma leve tração. Nesta etapa, notou-se que nas hastes pilo-
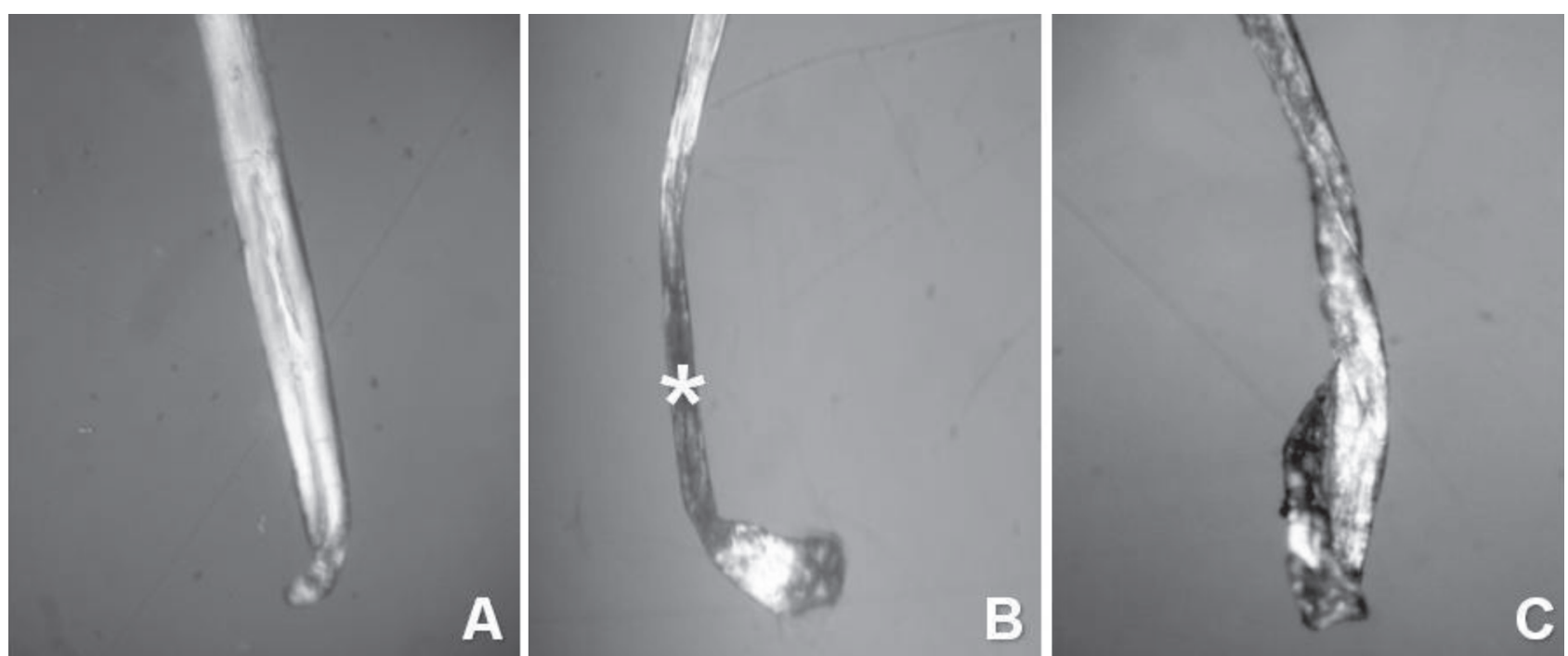

Fig.11. Alterações nas hastes pilosas de bovinos intoxicados por Ramaria flavo-brunnescens. Exame polaroscópico, obj.20x. (A) Haste pilosa normal (Bovino 16, no dia 0): a haste tem contornos e diâmetro regulares; além disso, há uma variação gradual nas cores. (B) Haste pilosa com área achatada sem polarização (*) (Bovino 7). (C) Haste pilosa com torção longitudinal do eixo (Bovino 16, no dia 5). 

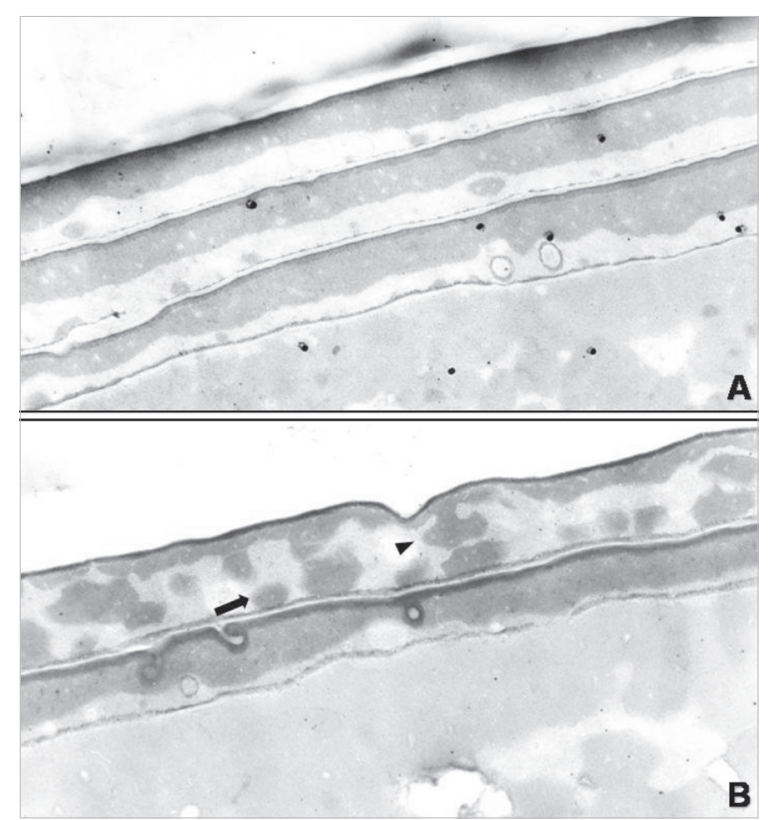

Fig.12. Fotomicrografia eletrônica das células cuticulares pilosas dos pelos da vassoura da cauda do Bovino 16, intoxicado experimentalmente por Ramaria flavo-brunnescens. Técnica de Swift sob microscopia eletrônica de transmissão. (A) Dia 0: as células cuticulares não apresentam alterações. Aumento 30.000x. (B) Dia 15: observa-se acentuada irregularidade da exocutícula (cabeça de seta), com inclusões cistina-positivas, arredondadas ou irregulares (seta) na endocutícula. Aumento 37.500x.

sas havia apenas fragmentos de BRI aderidos. Nos dias 10 e 15 as medidas do comprimento dos pelos permaneceram inalteradas e neste período os fragmentos de BRI aderidos às hastes se tornaram mais escassos ou ausentes.

O exame da cutícula pilosa do Bovino 16, através da técnica de microscopia eletrônica de transmissão com o uso da técnica de Swift, revelou marcada modificação na morfologia da exocutícula, porém, as alterações foram mínimas ou ausentes na camada $A$ da exocutícula. Foi observada irregularidade da exocutícula e inclusões anormais de cistina no interior da endocutícula (Fig.12A,B).

\section{DISCUSSÃo}

Alguns estudos têm descrito as alterações macroscópicas e microscópicas na intoxicação por Ramaria flavobrunnescens em animais domésticos, porém poucos trabalhos tiveram também como objetivo investigar (Kommers \& Santos 1995, Sallis et al. 2000, Schons et al. 2007) ou discutir (Barros et al. 2006) a patogênese das lesões.

Neste estudo, a patogênese da intoxicação foi investigada através da revisão de casos espontâneos e experimentais pela histopatologia e por métodos auxiliares na avaliação de defeitos da ceratinização na língua, esôfago, casco e cauda. Nos bovinos intoxicados experimentalmente, as lesões foram mais brandas, quando comparadas às presentes nos casos espontâneos. Observação seme-
Ihante havia sido feita anteriormente (Kommers \& Santos 1995). Explicações para esta diferença na intensidade das lesões estão provavelmente relacionadas com as características de termolabilidade e volatilidade relatadas para o princípio tóxico (Bauer et al. 1966, Fidalgo \& Fidalgo 1970, Kommers 1993, Sallis et al. 2004). Foram observadas variações na toxicidade do cogumelo em diferentes anos nos mesmos locais (Sallis et al. 2000), bem como diferenças na toxicidade do cogumelo após períodos intensamente chuvosos. Possíveis diferenças na suscetibilidade individual dos animais intoxicados também têm sido aventadas (Schons et al. 2007).

Na língua, a grande maioria das alterações histopatológicas observadas demonstrou defeitos na ceratinização, tais como desaparecimento das papilas filiformes, adelgaçamento, estratificação irregular, ceratinização lamelar focal e ceratinização individual de células (disceratose) no epitélio de revestimento dorsal.

As alterações relacionadas à ceratinização das papilas filiformes da língua dos bovinos deste estudo, estruturas que normalmente sofrem ceratinização dura (Banks 1991), puderam ser melhor observadas através da técnica do Tricrômico de Masson. Ao utilizar a técnica do Tricrômico de Masson nas línguas controle deste estudo, observou-se que a ceratina mole corava em vermelho e que a ceratina dura das papilas filiformes corava em amarelo. A mesma coloração amarela foi observada na ceratina dura do casco e nos pelos da cauda dos bovinos controles. Desta forma, além de ter sido uma ferramenta muito útil para diferenciar os tipos de ceratina, os defeitos na ceratinização dura também puderam ser melhor caracterizados. A coloração amarela das estruturas que sofrem ceratinização dura está provavelmente relacionada com a presença do ácido pícrico no protocolo de Tricrômico de Masson utilizado, pois as substâncias cornificadas demonstram grande afinidade por esse ácido (Fernandes 1949), o qual nem sempre está presente nas variações desta técnica. Com o uso desta técnica ficou evidente que nas papilas filiformes remanescentes há desestruturação e menor quantidade de ceratina dura.

Quando a técnica da oxidação seletiva da ceratina (OSC), a qual revela o conteúdo de cistina, principalmente na ceratina dura onde este é maior (Pearse 1951, Lillie \& Bangle 1954), foi aplicada às papilas filiformes linguais, a intensidade da coloração foi muito fraca, ficando evidente que há um baixo conteúdo de cistina na ceratina dura das papilas filiformes dos bovinos intoxicados.

Quanto à espessura epitelial, houve redução em todas as línguas e esôfagos analisados. $O$ adelgaçamento na espessura do epitélio lingual havia sido descrito na intoxicação espontânea (Barros et al. 2006) e na experimental (Kommers \& Santos 1995, Schons et al. 2007). Entretanto, o adelgaçamento na espessura do epitélio esofágico, visto em todos os bovinos deste estudo, não havia sido relatado na literatura consultada. Chamou a atenção o fato de que a redução na espessura do epitélio foi mais dramática nas áreas adjacentes às úlceras, es- 
pecialmente no epitélio lingual. $\mathrm{O}$ atrito ao epitélio lesado e a infecção bacteriana secundária possivelmente contribuem para o desenvolvimento das úlceras.

Algumas explicações têm sido propostas para justificar o adelgaçamento epitelial lingual. Por um lado pensou-se na possibilidade de uma interferência na multiplicação dos ceratinócitos linguais (Kommers \& Santos 1995). Análises do ciclo celular revelaram que a cisteína/ cistina estimula a proliferação celular em várias células (Noda et al. 2002). Vale lembrar que a cistina é o resultado da oxidação de duas cisteínas, com formação de pontes dissulfeto (Lehningher 1978). Como se acredita que haja interferência no metabolismo da cistina na intoxicação por R. flavo-brunnescens (Kommers \& Santos 1995), como será discutido posteriormente, esta possibilidade permanece plausível. Schons et al. (2007) tentaram confirmar esta teoria através de imunomarcação com Ki-67 (uma proteína que detecta células em proliferação), porém seus resultados foram inconclusivos devido ao reduzido número de amostras analisadas. Por outro lado foi discutida também a possibilidade de que haveria um marcado desgaste epitelial relacionado às alterações degenerativas observadas no epitélio dorsal da língua (Schons et al. 2007). Esta hipótese, também plausível, está baseada em achados de microscopia eletrônica (Barros 2005, Schons et al. 2007), nos quais se observou diminuição nos tonofilamentos dos ceratinócitos da camada espinhosa, talvez contribuindo para o aumento dos espaços intercelulares, facilitando uma diminuição da adesão entre os ceratinócitos com posterior desprendimento dos mesmos (Schons et al. 2007).

O tipo de avaliação morfológica realizada neste estudo confirmou a ocorrência do adelgaçamento epitelial lingual, porém não contribuiu para determinar sua origem. Alterações como estratificação irregular do epitélio associadas à ceratinização individual de células ou de pequenos grupos de ceratinócitos no epitélio oral podem indicar distúrbios na maturação celular (Morgan 1992). Da mesma forma, a presença de grande número de ceratinócitos disceratóticos também é associada a alterações no processo de ceratinização, uma vez que é um achado indicativo de defeito na diferenciação epitelial (Yager \& Wilcock 1994).

$\mathrm{Na}$ intoxicação espontânea pelo cogumelo, tem sido relatada a hiperemia do rodete coronário, podendo ocorrer perda do revestimento córneo dos cascos (Santos 1993). Nos casos experimentais as lesões macroscópicas geralmente limitaram-se à hiperemia do rodete coronário (Kommers \& Santos 1995) ou não havia alterações (Schons et al. 2007). Nos cascos dos bovinos aqui revisados havia somente alterações histológicas, observadas no estrato laminar. Estas se caracterizavam por graus variáveis de fusão, encurtamento, múltiplas camadas de células não-ceratinizadas no topo, ceratinização irregular e descontínua com persistência de núcleos, ceratinização individual e vacuolização de ceratinócitos das lâminas epidérmicas. Todas estas alterações revelam defeitos na ceratinização, os quais foram confirmados pelas técnicas de Tricrômico de Masson e OSC, conforme discutido para a língua.

Uma das alterações mais consistentemente observadas tanto nos casos espontâneos (Barros et al. 2006) como nos experimentais foi o afrouxamento e queda dos pelos da vassoura da cauda (Kommers \& Santos 1995, Schons et al. 2007), constituindo-se num dos achados mais característicos desta intoxicação. Lesões semelhantes as da intoxicação pelo cogumelo, principalmente as que envolvem a cauda e o casco, foram descritas na intoxicação crônica por selênio (alkali disease) em bovinos (O'Toole \& Raisbeck 1995). Nas análises publicadas até o momento, não foram observados níveis tóxicos de selênio no cogumelo (Freitas et al. 1966) nem em tecidos de animais intoxicados (Bauer et al. 1966). Vale salientar que essas análises do conteúdo de selênio foram realizadas há mais de 40 anos.

Em seções histológicas da região da vassoura da cauda dos bovinos deste estudo, as alterações puderam ser divididas, em lesões na parede folicular (bainhas radicular externa [BRE] e interna [BRI]) e naquelas que envolveram os pelos propriamente ditos. As alterações observadas no epitélio folicular, como desorganização e desalinhamento das células da BRE, à semelhança do que é visto no epitélio lingual, podem indicar distúrbios na maturação celular (Morgan, 1992). Da mesma forma, a presença de grande número de células disceratóticas indica defeito na diferenciação epitelial (Maruyama et al. 1994). Alterações foliculares (telogenização, ceratinização, disceratose) semelhantes às descritas nos bovinos deste estudo também foram relatadas na alkali disease (AD) em bovinos (O'Toole \& Raisbeck 1995). Na patogênese proposta para a $A D$, devido à semelhança química entre o selênio (Se) e o enxofre (S), acredita-se que as lesões epiteliais resultem da substituição do $S$ pelo Se nos resíduos de cisteína nas proteínas ricas em enxofre, com conseqüente enfraquecimento das ligações dissulfeto (Traub-Dargatz et al. 1986, O'Toole \& Raisbeck 1995).

Numa análise comparativa das lesões foliculares com as pilosas, observaram-se indícios de que as duas se sobrepõe, de forma que as alterações na morfologia do pelo possam ser resultantes tanto de defeitos no próprio pelo quanto decorrentes de uma parede folicular defeituosa, que modela em seu interior um pelo deformado. Numa alteração rara em humanos conhecida como pili torti, na qual são observadas alterações foliculares semelhantes às vistas na intoxicação de bovinos por $R$. flavo-brunnescens, irregularidades da estrutura da BRE podem ter como consequências deformidades sequenciais da BRI e do pelo, que dependendo do nível folicular não estão totalmente ceratinizados (Maruyama et al. 1994).

Nas seções histológicas, as principais alterações nas hastes pilosas demonstraram contornos irregulares, tortuosidade e desintegração da haste. Nas hastes pilosas desintegradas foi possível identificar, pela técnica do Tricrômico de Masson, somente fragmentos de hastes pilo- 
sas coradas em amarelo, indicando ceratinização dura defeituosa. Pela técnica da OSC, observou-se redução expressiva na coloração das hastes, confirmando a redução na quantidade de cistina, como descrita para as papilas filiformes e para as lâminas epidérmicas do casco.

O exame polaroscópico dos pelos permitiu uma boa identificação das alterações morfológicas e, adicionalmente, das alterações no padrão de birrefringência dos pelos. Muitas alterações morfológicas observadas nos pelos dos bovinos deste estudo foram semelhantes a condições que envolvem algum tipo de defeito relacionado à ceratinização descrita em humanos. Dentre elas destacam-se ondulação, achatamento e torção de hastes (Masaaki et al. 1984, Maruyama et al. 1994, Pereira 1997, Weedon 2002, Whiting \& Dy 2006). Nos pelos dos bovinos intoxicados por R. flavo-brunnescens as alterações no padrão de birrefringência (segmentos com ausência de polarização) são observadas nas áreas suprabulbares, correspondendo a porção do pelo que cresceu sob influência do princípio tóxico do cogumelo, e provavelmente refletem a redução do aminoácido cistina detectada nos pelos pela técnica da OSC nas seções histológicas da cauda.

O exame da cutícula pilosa do Bovino 16, através da microscopia eletrônica de transmissão com o uso da técnica de Swift (Swift 1967), revelou marcada modificação na morfologia da exocutícula, porém, as alterações foram mínimas ou ausentes na camada $A$ da exocutícula. Foi observada irregularidade da exocutícula e inclusões anormais de cistina no interior da endocutícula. A técnica de Swift (Swift 1967), sob microscopia eletrônica de transmissão, é considerada como um método histoquímico específico para a detecção do $S$ presente no aminoácido cistina, havendo uma correlação estequiométrica positiva entre a intensidade da coloração e a concentração de $S$ presente. Na cutícula de cabelos tricotiodistróficos, as camadas $\mathrm{A}$ e a exocutícula podem estar ausentes ou descontínuas e glóbulos de material eletrodenso (inclusões cistina-positivas anormais) podem ser identificados na camada A e no interior da endocutícula (Gummer et al. 1984, Khumalo et al. 2005), como vistas na endocutícula do Bovino 16. A tricotiodistrofia (TTD) é uma doença genética rara que acomete humanos e leva a formação de cabelos frágeis, com diâmetro e contornos irregulares, sendo associada à síntese anormal de proteínas ricas em enxofre, especialmente de cistina (Price et al. 1980, Itin \& Fistarol 2005). Apesar de não terem sido observadas alterações na camada $A$ da exocutícula no Bovino 16, as demais alterações são muito semelhantes às vistas na TTD, permitindo mais uma vez inferir que as alterações pilosas vistas na intoxicação pelo cogumelo estão relacionadas a um baixo conteúdo de cistina.

Em todos os tecidos avaliados não foram observadas lesões que corroborem com a patogênese proposta para a intoxicação por $R$. flavo-brunnescens em ovinos, onde a doença foi comparada ao ergotismo (Sallis et al. 2000).

\section{CONCLUSÃO}

Através deste estudo concluiu-se que a patogênese das lesões epiteliais na intoxicação por Ramaria flavo-brunnescens em bovinos envolve distúrbios na ceratinização mole e dura (principalmente), ligados possivelmente à proliferação, diferenciação e maturação de ceratinócitos, induzidos por marcada redução na cistina. As ulcerações observadas na língua e esôfago devem-se ao epiteliotropismo do princípio tóxico do cogumelo, com conseqüente adelgaçamento do epitélio de revestimento e ulcerações pelo atrito e infecção bacteriana secundária.

\section{REFERÊNCIAS}

Banks W.J. 1991. Histologia Veterinária Aplicada. Manole, São Paulo. 629p.

Barros R.R. 2005. Intoxicação por Ramaria flavo-brunnescens (Clavariaceae). Dissertação de Mestrado, Universidade Federal de Santa Maria, Camobi, Santa Maria, RS. 53p.

Barros R.R., Irigoyen L.F., Kommers G.D., Rech R.R., Fighera R.A. \& Barros C.S.L. 2006. Intoxicação por Ramaria flavo-brunnescens (Clavariaceae) em bovinos. Pesq. Vet. Bras. 26:87-96.

Bauer A.G., Laranja R.J. \& Santos A.G. 1966. Sobre a etiologia do chamado "Mal do Eucalipto". Arqs Inst. Vet. Desidério Finamor. 3:85-90.

Fernandes M.C. 1949. Métodos escolhidos de técnica microscópica. Imprensa Nacional, Rio de Janeiro. 615p.

Fidalgo O. \& Fidalgo M.E.P.K. 1970. A poisonous Ramaria from southern Brazil. Rickia. 5:71-91.

Freitas J., Pasturino C.L., Quiñones-Sowerby C.A., Bellagamba C., Giambruno E., Infantozzi J.M., Decia J.C. \& Gerveñanzky W. 1966. Comunicación sobre una enfermedad aparecida em ganados del Uruguay em los últimos años (Bocopa). $5^{\circ}$ Congr. Panam. Med. Vet. Zootec., Caracas, p.152-159.

Gummer C.L., Dawber R.P.R. \& Price V.H. 1984. Trichothiodystrophy: an electron-histochemical study of the hair shaft. Brit. J. Dermatol. 110:439-449.

Itin P. \& Fistarol S.K. 2005. Hair shaft abnormalities: Clues to diagnosis and treatment. Dermatol. 211:63-71.

Kommers G.D. 1993. Intoxicação experimental por Ramaria flavobrunnecens (Clavariaceae) em bovinos: estudo da patogenia das lesões dos cascos, cauda, chifres e língua. Dissertação de Mestrado, Universidade Federal de Santa Maria, Camobi, Santa Maria, RS. $63 p$.

Kommers G.D. \& Santos M.N. 1995. Experimental poisoning of cattle by the mushroom Ramaria flavo-brunnescens (Clavariaceae): A study of the morphology and pathogenesis of lesions in hooves, tail, horns and tongue. Vet. Hum. Toxicol. 37:297-302.

Khumalo N.P., Dawber R.P.R. \& Ferguson D.J.P. 2005. Apparent fragility of African hair is unrelated to the cystine-rich protein distribution: a cytochemical electron microscopic study. Exp. Dermatol. 14:311-314.

Lehningher A.L. 1978. Bioquímica. Vol.1. Edgar Blücher, São Paulo. 262p.

Lillie R.D. \& Bangle R. 1954. The peracetic acid Schiff reaction of hair cortex. J. Histochem. Cytochem. 2:300-310.

Maruyama T., Toyoda M., Kanei A. \& Morohashi M. 1994. Pathogenesis in pili torti: Morphological study. J. Dermatol. Sci. 7:5-12.

Masaaki I., Kaoru I. \& Hashimoto K. 1984. Pathogenesis in Trichorrhexis invaginata (bamboo hair). J. Invest. Dermatol. 83:1-6.

Morgan P.R. 1992. Neoplasms and precancerous conditions of the oral mucosa, p.1059-1067. In: McGee J.O., Isaacson P.G. \& Wright N.A. (Eds), Oxford Textbook of Pathology. Vol.1. Oxford University Press, Oxford. 2344p. 
Noda T., Iwakiri R., Fujimoto K., Rhoads C.A. \& Aw T.Y. 2002. Exogenous cysteine and cystine promote cell proliferation in CaCo-2 cells. Cell. Prolif. 35:117-129.

O'Toole D. \& Raisbeck M.F. 1995. Pathology of experimentally induced chronic selenosis (alkali disease) in yearling cattle. J. Vet. Diagn. Invest. 7:364-373.

Pearse A.G.E. 1951. The histochemical demonstration of keratin by methods involving selective oxidation. Quart. J. Micr. Sci. 92:393-402.

Pereira A.L.M. 1997. Moniletrix: relato de caso. Anais Bras. Dermatol. 72:455-457.

Price V.H., Odom R.B., Ward W.H. \& Jones F.T. 1980. Trichothiodystrophy: Sulfur-deficient brittle hair as marker for a neuroectodermal symptom complex. Arch. Dermatol. 116:1375-1384.

Sallis E.S.V., Riet-Correa F., Raffi M.B. \& Méndez M.C. 2000. Experimental intoxication by the mushroom Ramaria flavo-brunnescens in sheep. Vet. Human. Toxicol. 42:321-324.

Sallis E.S.V., Raffi M.B. \& Riet-Correa F. 2004. Intoxicação experimental em ovinos com Ramaria flavo-brunnescens congelada ou dessecada. Pesq. Vet. Bras. 24:107-110.

Santos M.N., Barros S.S. \& Barros C.S.L. 1975. Intoxicação em bovinos pelo cogumelo Ramaria flavo-brunnescens. Pesq. Agropec. Bras., Sér. Vet. 10:105-109.
Santos M.N. 1993. Intoxicação por Ramaria flavo-brunnescens, p.309318. In: Riet-Correa F., Méndez M.C. \& Schild A.L. (Eds), Intoxicações por Plantas e Micotoxicoses em Animais Domésticos. Editorial Agropecuária Hemisfério Sul do Brasil, Pelotas. 340p.

Schons S.V., Kommers G.D., Pereira G.M., Raffi M.B. \& Schild A.L. 2007. Estudo histológico, imuno-histoquímico e ultra-estrutural das lesões induzidas experimentalmente por Ramaria flavo-brunnescens (Clavariaceae) em bovinos. Pesq. Vet. Bras. 27:269-276.

Swift J.A.1967. The electron histochemistry of cystine-containing proteins in thin transverse sections of human hair. J. Royal Microsc. Soc. 88:449-469.

Tokarnia C.H., Döbereiner J. \& Peixoto P.V. 2000. Plantas Tóxicas do Brasil, p.206-209. Editora Helianthus, Rio de Janeiro. 310p.

Traub-Dargatz J.L., Knight A.P. \& Hamar D.W. 1986. Selenium toxicity in horses. Commpend. Cont. Ed. 8:771-776.

Weedon D. 2002. Skin Pathology. Churchill Livingstone, Philadelphia. 1158p.

Whiting D.A. \& Dy L.C. 2006. Office diagnosis of hair shaft defects. Sem. Cutan. Med. Surg. 25:24-34.

Yager J.A. \& Wilcock B.P. 1994. Color Atlas and Text of Surgical Pathology of the Dog and Cat: Dermatopathology and skin tumors. Wolfe, London. 320p. 